\title{
Problems and Issues in Corporate Restructuring in the State-Owned Construction Sector in Vietnam: The Case of VINACONEX
}

\author{
Nguyen Ngoc Thang ${ }^{1}$ \\ ${ }^{1}$ Hanoi School of Business, Vietnam National University, Vietnam \\ Correspondence: Nguyen Ngoc Thang, 144 Xuan Thuy str., Cau Giay dist, Hanoi, Vietnam. Tel: 84-94-661-1417. \\ E-mail: thangnn@vnu.edu.vn
}

Received: July 28, 2014 Accepted: August 29, 2014 Online Published: October 30, 2014

doi:10.5539/ass.v10n22p291 URL: http://dx.doi.org/10.5539/ass.v10n22p291

\begin{abstract}
The study of corporate restructuring in state-owned enterprises has been a hot topic in the academic world. However, little study has been done in investigating the corporate restructuring in state-owned enterprises in Vietnam. This study is devoted to exploring the problems and issues of corporate restructuring in a specific construction company in Vietnam. This study aims to investigate what problems and issues arise in the corporate restructuring of a construction company. A typical five-level Likert item questionnaire was designed for the data collection. Data from 398 respondents show that the company's restructuring decision was determined by the company's internal and external factors. VINACONEX needs to pay more attention to management training for managers and to carrying out technological innovation. From the findings, we propose some solutions to deal with problems arising from the restructuring of VINACONEX. The results of the study provide more evidence for the theories about corporate restructuring and contribute to the growing knowledge in strategic management by using a specific Vietnamese case. In this study, we also draw some limitations and recommendations for future research.
\end{abstract}

Keywords: corporate restructuring, state-owned enterprises, VINACONEX

\section{Introduction}

Vietnam embarked on the Doi Moi (renovation) policy in 1986. Since then, the country has experienced radical changes, first and foremost in its fundamental economic thinking. The centrally planned economy à la the Soviet Union was replaced by a market economy, albeit of a socialist character, which started with a sweeping restructuring of the state-owned sector. This allowed the private sector to join the economy, which facilitated the process of full integration into the region and world mainstream. The Doi Moi (renovation), economic growth, competition and globalization, along with tightened fiscal policies are causing both the private and public sector Vietnamese enterprises to strive for greater efficiency and higher cost-effectiveness. In many cases the desired results cannot be achieved without subjecting the corporate strategy and structure to some transformation. In this context, restructuring is no longer just an option. It is a necessity for survival and growth (Cascio, 2002).

Privatization and restructuring of the state-owned enterprise (SOE) sector in Vietnam is intended to concentrate state ownership and control on a core of large enterprises in strategic industries while withdrawing state ownership and support from small and medium-sized enterprises. SOE restructuring is closely linked to the economic restructuring of the enterprise sector as a whole and to corporate governance reforms (CIEM, 2006). Creation of the strategic core of large SOEs involves their conversion into modern enterprises and the formation of large enterprise groups that will be able to compete against large foreign multinationals. These groups face important challenges in overcoming the present problem of their SOEs and in sustaining the efficiency and flexibility that will be needed to compete successfully in international markets.

The Vietnam Construction and Import-Export Joint Stock Corporation (VINACONEX) is a state-owned enterprise. Since the Corporation was established, VINACONEX has followed a diversification strategy on production and business aspects, gained many proud achievements as well as being highly appreciated by clients, the business community and society. However, lately, in the context of a complicated and unexpected ever-changing macroeconomic climate characterized by greatly increasing inflation at levels not experienced for many years, signs of emerging deflation, a tight monetary policy, a tight real estate policy, and the Government's cutting of public investment, etc., enterprises in the construction sector in general, and VINACONEX in 
particular, have coped with a great many difficulties. This study will investigate the problems and issues related to the restructuring of VINACONEX.

\section{Analyzing Framework}

Organizational restructuring involves major changes in the organizational structure for enhancing the 'efficiency and effectiveness' of firms (Bowman \& Singh, 1993). It involves reorientation of business units to rearrange resources within a firm for better performance. According to Gibbs (1993), there are three types of corporate restructuring. These include: (i) financial restructuring including recapitalizations and changes in capital structure; (ii) portfolio restructuring involving refocusing on core business, resulting in change in the diversity of business in the corporate portfolio; and (iii) operational restructuring, including reorganization and changes in business-level strategies (Gibbs, 1993).

Corporate restructuring is intended to either react to crisis or to be part of the company's pre-emptive plan for their survival in the industry. The restructuring process is a lengthy and a painstaking one. It presents many challenging tasks and requires analysis of social benefits and costs. The most difficult task is to persuade those who are most affected to understand the desirability of the reform efforts (Soon, 2004). In the meantime, strategic evaluation of re-engineering, restructuring, and downsizing policies is perceived as the influential management paradigm. With this, companies are able to fully leverage on their core competences in creating superior competitiveness (Tony, 1997).

Miller and Friesen (1984) suggested that environment shift, technology changes, organizational growth, and leadership changes are the reasons that lead to restructuring (Miller \& Friesen, 1984)]. Massimo and Delmastro (2002) deemed that the adaptation of advanced manufacturing technology and new human resource management practices favors organizational change (Colombo \& Delmastro, 2002). King, Covin and Heeley (2000) suggested that environmental dynamism impacts the strategies chosen by firms and moderates the relationships between the organizational structure, organizational strategies, and firm performance (King, Covin, \& Hegarty, 2003). Moers (2000) suggested that restructuring is also associated with strong market competition (Moers, 2010). Jensen (1986) believed that the restructuring could be described as returning a free cash flow to owners (Jensen, 1986). The work of Harrison et al. (1991) suggested that a significant amount of restructuring is associated with high levels of diversification strategies (Harrison, Hitt, Hoskisson, \& Ireland, 1991), while the study of Hoskisson and Turk (1990) concluded that restructuring is primarily directed at overcoming control problems that are associated with diversification and that result in poor performance (Hoskisson \& Turk, 1990). It is partially explained by free cash flow, because free cash flow is a function of investment opportunity, operating cash flow, diversification, financial leverage, and corporate governance. Hill and Snell (1988) found that ownership concentration was associated with lower levels of diversification in research and development intensive firms (Hill \& Snell, 1988). Thus ownership diffusion is positively related to diversification. Based on this literature, we proposed an analyzing framework indicating the relationship between the dependent variable (corporate restructuring) and independent variables as presented in figure 1.

\section{Methodology}

\subsection{Sample Determination}

Slovin's formula was used to define the sample size for the survey in this study:

$$
\mathrm{n}=\mathrm{N} /\left(1+\mathrm{N} * \mathrm{e}^{2}\right)
$$

Where n: sample size

$\mathrm{N}$ : Population size is the total number of staff members of VINACONEX.

e: Probability of error committed due to the use of the sample instead of the total population. The error level in the sample survey was chosen to be at 5 percent.

At the time of the survey, VINACONEX had 34,201employees. Thus, the minimum sample size to conduct the investigations would be:

$$
\mathrm{n}=\mathrm{N} /\left(1+\mathrm{N}^{*} \mathrm{e}^{2}\right)=34,201 /\left(1+34201 * 0.05^{2}\right)=395
$$

\subsection{Research Design and Data Collection}

To collect data for this study, a questionnaire was developed in both English and Vietnamese as the instrument. The questionnaire was developed based on the analyzing framework (Figure 1). It consists of 30 statements related to competition, finance, corporate governance, new business strategies, human resource management, conflict, ownership, leadership, technology development, and the company's development, in order to gain 
in-depth knowledge on all the issues. A typical five-level Likert item (Agreement scale from $1=$ strongly disagree to $5=$ strongly agree) was used for this study (see Appendix).

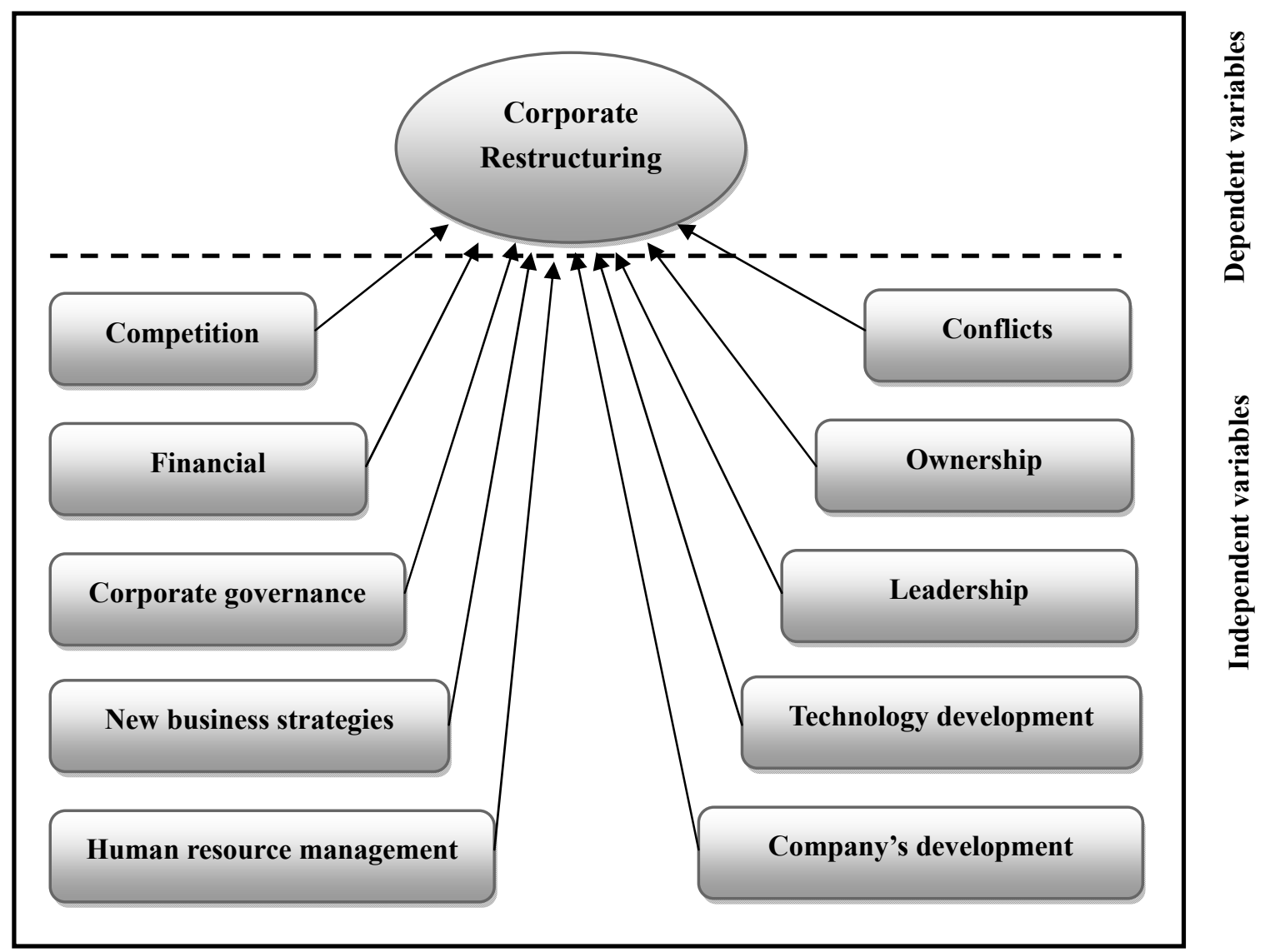

Figure 1. An analyzing framework

Table 1. Respondent demographics about the study sample

\begin{tabular}{lll}
\hline Demographic information & Number of respondents & Percentage \\
\hline Gender & 363 & \\
Male & 35 & 91.20 \\
Female & & 8.80 \\
Job positions & 111 & \\
Senior executives & 128 & 27.89 \\
Managing directors & 159 & 32.16 \\
Officers & & 39.95 \\
Educational levels & 8 & \\
College graduate & 313 & 2.01 \\
University graduate & 77 & 78.64 \\
Postgraduate & & 19.35 \\
Work experience & 15 & \\
Less than 5 years & 32 & 3.77 \\
$5-10$ & 207 & 8.04 \\
$10-15$ & 144 & 52.01 \\
15 years and more & & 36.18 \\
\hline
\end{tabular}


The data collection process took place from May to June, 2013 through mixed-mode surveys. On one hand, we conducted face-to-face interviews at four training courses for VINACONEX's middle managers. On the other hand, questionnaires were handed to the respondents at VINACONEX by these middle managers. At the end, we collected 398 questionnaires with full information.

\section{Results and Discussion}

Table 1 indicates that the majority of respondents are males ( 91.2 percent) and only 8.8 percent are females (35/398 persons). The sample was suitable having the characteristics of the construction sector where the majority of employees in the industry are males. Table 1 also shows that most of the respondents were university graduated employees and have had more than five-year's working experience.

Regarding job position, results in Table 1 indicate that 27.89 percent are senior executives (General Director, Deputy General Directors, Directors, Deputy Directors, Chief of Trade Union, etc.), 32.16 percent are managing directors (including directors of human resources, finance, departments, divisions, etc.) and 39.95 percent are officers (such as leaders of construction teams, accountants, department officers, etc.). This shows that most of the respondents are relevant to the restructuring process of the enterprise and nearly 60 percent of them are executives, directors or managers at various levels. It can be said that through these samples, the survey results are appropriate to the reality and will reflect reliably the research theme.

\subsection{Findings}

The content relating to the restructuring process in VINACONEX is categorized into 10 major issues including competition, developmental strategies, finance, corporate governance, human resource management, leadership, ownership, conflicts, technology development, and company development. Key survey results are shown below.

Table 2. Reasons for corporate restructuring

\begin{tabular}{|c|c|c|c|c|c|}
\hline \multirow{3}{*}{$\begin{array}{l}\text { The reasons for state-owned construction companies in Vietnam to } \\
\text { implement restructuring }\end{array}$} & \multicolumn{5}{|c|}{ Frequency } \\
\hline & \multicolumn{5}{|c|}{$\begin{array}{l}\text { The level of agreement is } \\
\text { increasing }\end{array}$} \\
\hline & 1 & 2 & 3 & 4 & 5 \\
\hline $\begin{array}{l}\text { Restructuring comes from the pressures and requirements of the Group/Parent } \\
\text { Company/State Capital management Company/Industry/Government }\end{array}$ & 7 & 142 & 213 & 20 & 16 \\
\hline $\begin{array}{l}\text { Restructuring results from the urgent needs of the company to help it overcome } \\
\text { recession, or avoid bankruptcy }\end{array}$ & 3 & 4 & 29 & 67 & 295 \\
\hline $\begin{array}{l}\text { Restructuring has arisen from the company itself with the objective of } \\
\text { self-renewal suitable with its strategy and the needs of the business } \\
\text { development-identifying that restructuring is an indispensable phase in the } \\
\text { development process of the company }\end{array}$ & 62 & 163 & 96 & 34 & 43 \\
\hline
\end{tabular}

Table 3. The respondents on competition

\begin{tabular}{|c|c|c|c|c|c|}
\hline \multirow{3}{*}{ Competition } & \multicolumn{5}{|c|}{ Frequency } \\
\hline & \multicolumn{2}{|c|}{$\begin{array}{l}\text { The level } \\
\text { increasing }\end{array}$} & \multicolumn{3}{|c|}{ of agreement is } \\
\hline & 1 & 2 & 3 & 4 & 5 \\
\hline Restructuring helps company compete more effectively & 1 & 73 & 264 & 40 & 20 \\
\hline $\begin{array}{l}\text { Restructuring helps companies focus their resources on their competitive } \\
\text { products and the market }\end{array}$ & 1 & 2 & 18 & 96 & 281 \\
\hline $\begin{array}{l}\text { Restructuring helps companies focus on improving the quality of customer } \\
\text { services, and enhancing the company' image and trademark }\end{array}$ & 62 & 245 & 43 & 35 & 13 \\
\hline
\end{tabular}

The survey results in table 2 show that the majority of respondents (362/398 respondents, accounting for approximately 90.1 percent) agreed and strongly agreed with the reason that the restructuring resulted from the urgent needs of the company and were aimed at helping it to overcome recession, or avoid bankruptcy. The intent of the restructuring was to help the company improve competition, effectiveness and efficiency. 
Regarding competition, table 3 indicates that the majority of respondents (375/398 respondents, accounting for approximately 94.22 percent) agreed that the restructuring helped company focus their resources on their competitive products in the market. On the contrary, most of the opinions (over 77 percent) disagreed that the restructuring helped company focus on improving the quality of customer services, and enhancing the images and trademark of the company. Thus, the company needed to allocate capital and other resources more adequately and efficiently, concentrated on core business areas related to the construction industry.

Table 4. The respondents on strategy

\begin{tabular}{|c|c|c|c|c|c|}
\hline \multirow{3}{*}{ Strategy } & \multicolumn{5}{|c|}{ Frequency } \\
\hline & \multicolumn{2}{|c|}{$\begin{array}{l}\text { The level } \\
\text { increasing }\end{array}$} & \multicolumn{3}{|c|}{ of agreement is } \\
\hline & 1 & 2 & 3 & 4 & 5 \\
\hline $\begin{array}{l}\text { In the context of Vietnam, construction companies should focus on their core } \\
\text { business areas related to the construction industry }\end{array}$ & 9 & 25 & 49 & 172 & 143 \\
\hline $\begin{array}{l}\text { Having a clear strategy is a prerequisite to conduct restructuring. Otherwise, a } \\
\text { hasty restructuring could result in decline, crisis, or even lead to bankruptcy. }\end{array}$ & 0 & 23 & 232 & 103 & 40 \\
\hline $\begin{array}{l}\text { Construction companies in Vietnam should expand their business in } \\
\text { developing markets where infrastructure and construction is still } \\
\text { underdeveloped }\end{array}$ & 162 & 76 & 112 & 35 & 13 \\
\hline
\end{tabular}

Table 5. The respondents on conflict

\section{Conflict}

Table 6. The respondents on ownership

\section{Ownership}

Restructuring causes dissent amongst workers as well as trade unions

In restructuring it is essential to dismantle and replace the old structure with a new one, so that there is a sharp contrast between the old and the new in terms of conditions and benefits

Restructuring will require companies to put off staff which will mean they will also face fierce resistance from a number of their own managers and employees

\begin{tabular}{|c|c|c|c|c|}
\hline \multicolumn{5}{|c|}{ Frequency } \\
\hline \multicolumn{5}{|c|}{$\begin{array}{l}\text { The level of agreement is } \\
\text { increasing }\end{array}$} \\
\hline 1 & 2 & 3 & 4 & 5 \\
\hline 9 & 82 & 260 & 34 & 15 \\
\hline 6 & 36 & 71 & 135 & 152 \\
\hline 6 & 26 & 152 & 183 & 32 \\
\hline
\end{tabular}

\begin{tabular}{llllll}
\hline Ownership & $\begin{array}{l}\text { Frequency } \\
\text { The level of } \\
\text { increasing }\end{array}$ & & & \\
& $\mathbf{1}$ & $\mathbf{2}$ & $\mathbf{3}$ & $\mathbf{4}$ & $\mathbf{5}$ \\
\hline $\begin{array}{l}\text { The profound understanding and compatibility of the business operation fields } \\
\text { of the VINACONEX, who owned the main shares of the VINACONEX, will } \\
\text { substantially affect the success or failure the VINACONEX }\end{array}$ & 6 & 34 & 43 & 75 & 240 \\
$\begin{array}{l}\text { Enhancing the role of independent directors in the Board of Management shall } \\
\text { help keep the restructuring on the right track and improve the risk management } \\
\text { of the VINACONEX }\end{array}$ & 20 & 182 & 101 & 70 & 25 \\
$\begin{array}{l}\text { Contributions of state shareholders in companies are not realistic, and are } \\
\text { poorly effective for the business operations of the VINACONEX that have } \\
\text { controlling shares owned by the State }(>51 \text { percent) }\end{array}$ & 11 & 87 & 149 & 150 \\
\hline
\end{tabular}

Among four strategy-related issues, it is obvious that 315 respondents agreed that in the context of Vietnam, the construction companies should focus on their core business areas related to the construction industry (table 4). In 
addition, many respondents (143 respondents) noted that having a clear strategy was a prerequisite to conduct restructuring; otherwise, a hasty restructuring could result in decline, crisis, or even lead to bankruptcy. 238 respondents disagreed with expanding the business in developing markets where infrastructure and construction is still underdeveloped.

The respondents on conflict in Table 5 show that the highest concern of many people is that in restructuring it is essential to dismantle the old structure and replace it with a new one, so that there is a sharp contrast between the old and the new in terms of conditions and benefits. Any company when implementing restructuring always copes with this matter. Moreover, the restructuring will require the companies to put off staff. This means that they will also face fierce resistance from a number of their own managers and employees. This is an issue that captured much attention and has the agreement of many respondents.

Regarding ownership, Table 6 shows that most of the respondents (nearly 80 percent) agreed and strongly agreed with the first statement saying: "the profound understanding and compatibility of the business operation fields of those companies, who own the shares of the company, will substantially affect the success or failure of the company". In addition, 299 respondents agreed that the contributions of state shareholders in companies are not realistic, and are poorly effective for the business operations of the companies that have controlling shares owned by the State $(>51$ percent).

Table 7. The respondents on leadership

\begin{tabular}{|c|c|c|c|c|c|}
\hline \multirow{3}{*}{ Leadership } & \multicolumn{5}{|c|}{ Frequency } \\
\hline & \multicolumn{5}{|c|}{$\begin{array}{l}\text { The level of agr } \\
\text { increasing }\end{array}$} \\
\hline & 1 & 2 & 3 & 4 & 5 \\
\hline $\begin{array}{l}\text { Restructuring must begin with the awareness of the leaders of the } \\
\text { VINACONEX }\end{array}$ & 14 & 89 & 78 & 166 & 51 \\
\hline $\begin{array}{l}\text { The Board of Management members, who directly manage the business } \\
\text { operations, will play the decisive role in the success or failure of the } \\
\text { restructuring process in particular and the development of the VINACONEX in } \\
\text { general }\end{array}$ & 2 & 10 & 123 & 220 & 43 \\
\hline $\begin{array}{l}\text { The qualification, knowledge and the profession of board members in the } \\
\text { operation fields of the VINACONEX will greatly impact on the success of the } \\
\text { restructuring }\end{array}$ & 1 & 4 & 33 & 121 & 237 \\
\hline
\end{tabular}

Table 8. The respondents on employment

\begin{tabular}{|c|c|c|c|c|c|}
\hline \multirow{3}{*}{ Employment } & \multicolumn{5}{|c|}{ Frequency } \\
\hline & \multicolumn{3}{|c|}{$\begin{array}{l}\text { The level of } \\
\text { increasing }\end{array}$} & \multicolumn{2}{|c|}{ agreement is } \\
\hline & 1 & 2 & 3 & 4 & 5 \\
\hline Restructuring means the downsizing of staff of the VINACONEX & 8 & 15 & 61 & 165 & 149 \\
\hline $\begin{array}{l}\text { Restructuring is an opportunity to appropriately adjust key positions in the } \\
\text { VINACONEX and it is the right time to attract high quality human resources } \\
\text { from the outside of the VINACONEX }\end{array}$ & 14 & 17 & 106 & 221 & 40 \\
\hline $\begin{array}{l}\text { Restructuring help the VINACONEX to recognize the important role of human } \\
\text { resources strategy as well as its implementation }\end{array}$ & 31 & 67 & 228 & 55 & 17 \\
\hline
\end{tabular}

Leaders play an important and direct role in the success or failure of the corporate restructuring process. In table 7, there are 358/398 respondents (nearly 90 percent) confirming that the qualifications, knowledge and the profession of Board of Management members in the operation fields of the VINACONEX will greatly impact the success of the restructuring. This is consistent with the results in the first statement in the table 7 . It means that the restructuring should start from the awareness of the leaders. In addition, most of the respondents were in favor of the opinion that BOM's members, who directly manage the business operations, should play the 
decisive role in the success or failure of the restructuring process in particular and the development of the VINACONEX in general.

Employment is a sensitive issue during the restructuring process. Table 8 shows that most of the respondents (nearly 79 percent) agreed that restructuring means the downsizing of the staff of the Companies. 261 respondents stated that restructuring is an opportunity to appropriately adjust key positions in the companies, and it is the right time to attract high quality human resources from outside the VINACONEX. In addition, some respondents agreed that the restructuring helps the VINACONEX to recognize the important role of human resources strategy as well as its implementation.

Table 9 shows that technological innovation is the only one of the 10 issues in the questionnaires that contains 3 statements which are highly agreed to by respondents. Of these three, the statement "Technological innovation should be carried out continuously. It should not wait until restructuring to carry out the technological innovation" was agreed to the most with 84 percent of respondents agreeing (of these respondents over 54 percent strongly agreed and nearly 30 percent agreed). Only 5 respondents (equivalent to 1.26 percent) disagreed with this statement. Thus, technological innovation is the leading issue in the restructuring of VINACONEX.

Table 9. The respondents on technological innovation

\begin{tabular}{|c|c|c|c|c|c|}
\hline \multirow{3}{*}{ Technological Innovation } & \multicolumn{5}{|c|}{ Frequency } \\
\hline & \multicolumn{3}{|c|}{$\begin{array}{l}\text { The level of } \\
\text { increasing }\end{array}$} & \multicolumn{2}{|c|}{ agreement } \\
\hline & 1 & 2 & 3 & 4 & 5 \\
\hline One of the leading issues in the restructuring is technological innovation & 3 & 44 & 63 & 110 & 178 \\
\hline $\begin{array}{l}\text { Restructuring relating to technology should be defined as: "technological } \\
\text { innovation should be carried out before the current technology is outdated" }\end{array}$ & 16 & 67 & 155 & 36 & 124 \\
\hline $\begin{array}{l}\text { Technological innovation should be carried out continuously. Implementation } \\
\text { of technological innovation should not wait until restructuring. }\end{array}$ & 0 & 5 & 59 & 114 & 220 \\
\hline
\end{tabular}

Regarding the corporate governance issue, table 10 shows that most respondents (approximately 85 percent) agreed that restructuring relating to corporate governance was to comprehensively reform the management approach and methods in the VINACONEX rather than to establish and build uniform regulations and procedures for meeting the strategy of the VINACONEX in accordance with the implementing of the roadmap of the restructuring.

Table 10. The respondents on corporate governance

\begin{tabular}{lllllll}
\hline Corporate Governance & \multicolumn{3}{c}{$\begin{array}{l}\text { Frequency } \\
\text { The } \\
\text { increasing }\end{array}$} \\
& $\mathbf{1}$ & $\mathbf{2}$ & $\mathbf{3}$ & $\mathbf{4}$ & $\mathbf{5}$ \\
\hline $\begin{array}{l}\text { Restructuring relating to corporate governance is to comprehensively reform } \\
\text { the management approach and methods in the VINACONEX }\end{array}$ & 0 & 8 & 53 & 142 & 195 \\
$\begin{array}{l}\text { Establishing and building uniform regulations and procedures is necessary to } \\
\text { meet the strategy of the VINACONEX in accordance with the implementing } \\
\text { of the roadmap of the restructuring }\end{array}$ & 38 & 161 & 61 & 93 & 45 \\
$\begin{array}{l}\text { Mergers and acquisitions should occur more frequently } \\
\text { is }\end{array}$ & 14 & 67 & 215 & 87 & 15 \\
\hline
\end{tabular}

Table 11 indicates that most respondents were concerned about the policies of the state on capital preservation requirements for selling shares or conducting mergers, which were creating obstacles for the restructuring process. For the same reason, they agreed with the opinion that there should be a specific policy regarding "capital preservation requirements" for selling projects/shares of state owned enterprises/companies with the controlling shares owned by the State. Additionally, about 40 percent of the respondents wished the state to have a flexible policy on the purchase and sale of debts in order to help VINACONEX to accelerate the restructuring 
process. Only a few respondents agreed with the opinion that the merger, acquisition or sale of its affiliates/subsidiaries is actually to help improve the financial condition of the VINACONEX.

Table 11. The respondents on finance

\begin{tabular}{|c|c|c|c|c|c|}
\hline \multirow{3}{*}{ Finance } & \multicolumn{5}{|c|}{ Frequency } \\
\hline & \multicolumn{3}{|c|}{$\begin{array}{l}\text { The level of } \\
\text { increasing }\end{array}$} & \multicolumn{2}{|c|}{ agreement is } \\
\hline & 1 & 2 & 3 & 4 & 5 \\
\hline $\begin{array}{l}\text { The merger, acquisition or sale of its affiliates/subsidiaries is actually to help } \\
\text { improve the financial condition of the companies }\end{array}$ & 31 & 96 & 225 & 29 & 17 \\
\hline $\begin{array}{l}\text { There should be a specific policy regarding "capital preservation requirements" } \\
\text { for selling projects/shares of state owned enterprises/companies with } \\
\text { controlling shares owned by the State }\end{array}$ & 2 & 11 & 42 & 140 & 203 \\
\hline $\begin{array}{l}\text { Inconsistent policies of the state on capital preservation requirements for } \\
\text { selling shares or conducting merger are creating obstacles for the restructuring } \\
\text { process }\end{array}$ & 2 & 7 & 43 & 81 & 265 \\
\hline
\end{tabular}

\subsection{Implications}

The findings of the study may provide the company with the following practical implications, which may also be useful for many other Vietnamese construction companies in restructuring.

First, VINACONEX needs to develop a new corporate strategy after corporate restructuring in order to implement an ambitious and long-term view about company development. The success and development of the company are primarily based on the strategic vision and mission. In order to implement the strategic plan, the company needs to inform everyone in the VINACONEX of the new plan so people can understand they company's tasks and their tasks in helping the VINACONEX (to?) reach the objectives. In addition, VINACONEX needs to create, maintain and develop channels of communication between the VINACONEX, the unit members and the shareholders.

Second, the focus should be on two main areas of business-the construction and real estate business-because it is in these two areas that VINACONEX has a highly competitive advantage. More specifically, VINACONEX needs: (i) to withdraw from the business sector that is dominated by companies operating commercial bank and financial services-sectors in which VINACONEX has a low comparative advantage. (ii) to continue to search and implement real estate projects and infrastructure development of large-scale, highly profitable businesses and ensure the long-term stable development of these member companies in VINACONEX, and to enhance the credibility and trademarks of member companies.

Third, the VINACONEX needs to provide training programs for both staff and managers. As mentioned above in the method chapter, some staff and managers in the VINACONEX do not understand some concepts relating to management and corporate restructuring. In addition, after restructuring, the VINACONEX's environment will change and become more dynamic and competitive. The mismatched business and management practices of the company and business partners would at the least mean they were ineffective and inefficient. Therefore, the knowledge of management and business has become more crucial for the company's long-term success.

Fourth, the VINACONEX needs to improve firm performance through technology development and innovation because technological innovation is one of the important issues that often go together with the restructuring process. In addition, the company needs also pay more attention to competition through technology instead of through the unskilled labor force.

Finally, the VINACONEX needs to build standards and conditions for each key position, such as members of the Management Board, Supervisory Board, Board of Directors, Chief Financial Officer, and Board of Directors of VINACONEX. These are criteria for review work efficiency of these key positions. In addition, the company needs to assign responsibilities and encourage coordination between the Board of Directors and the Supervisory Board in all activities of the company after restructuring.

\subsection{Limitations and Recommendations for Future Research}

Although our study provides interesting insights about the problems and issues related to the restructuring of VINACONEX, some important limitations of this study should be emphasized. 
First, corporate restructuring has recently faced widespread criticism due to its low-turnaround success rate in Vietnam. Our analysis extends beyond this discussion by investigating the problems and issues at a specific company. Based on theoretical findings, we develop an analyzing framework for this study. However, the scope of this research is limited to specific research aspects and some variables may be missing. Future research may contribute more variables to build up a better conceptual framework for such a broad investigation.

Second, the application of the findings of this study may have its limitations because the study has investigated problems and issues related to the restructuring of a specific company. Future research should further explore to what extent a broader survey research approach, with larger sample size, may overcome the shortcomings of this study.

Third, this study focuses on a corporation in the construction sector in Vietnam. There is some question as to how well these results generalize to State-owned enterprises in other sectors. Future research needs to conduct more study on corporate restructuring State-owned enterprises in different sectors in order to provide a more detailed picture about restructuring in Vietnam.

Finally, this study analyzes the problems and issues in corporate restructuring in a specific state-owned enterprise. In this study, we use a typical five-level Likert scale to measure problems and issues. Future research should use other restructuring measures in order to shed new light on the determinants of corporate restructuring of State-owned enterprises in Vietnam.

\section{Conclusion}

Based on the combination of scientific reasoning, the results of research and from practical problems arising in the development process of VINACONEX, the author has compiled the following suggestions:

First, VINACONEX needs to focus on two major business areas to achieve its vision, which is to become the leading company in the area of development, investment and management of Construction and Real Estate.

Second, the implementation of corporate restructuring in accordance with the actual conditions of SOEs and the construction market situation in Vietnam is now an essential requirement and is the effective way in business. Third, VINACONEX needs to develop an effective management mode that is transparent to avoid risks better. The implementation of the restructuring initiative will help VINACONEX's future development.

Fourth, VINACONEX needs to develop strategies for long-term financial management to ensure the sustainable development of the corporation. The company needs a clear organizational structure, focusing on the areas of core business strategy, leveraging the development of key sectors of the Corporation.

Finally, VINACONEX needs to manage and better exercise control by increasing accountability for the operation of member companies. In addition, there needs to be greater transparency in corporate governance to help investors better understands the activities of VINACONEX.

\section{Author}

Nguyen Ngoc Thang is currently Vice Dean and a lecturer in Human Resource Management and Change Management at Hanoi School of Business, Vietnam National University, Hanoi. He holds a MBA from Southern California University, USA and a PhD in Applied Economic Sciences from the Faculty of Economics and Business Administration, Ghent University, Belgium. He has published several articles on training and development, human resource management and firm performance in Vietnam.

\section{References}

Bowman, E. H., \& Singh, H. (1993). Corporate Restructuring: Reconfiguring the Firm. Strategic Management Journal, 14, 5-14. http://dx.doi.org/10.1002/smj.4250140903

Cascio, W. F. (2002). Strategies for responsible restructuring. Academy of Management Executive, 16, 80-91. http://dx.doi.org/10.5465/AME.2002.8540331

CIEM. (2006). Vietnam's Economy in 2005. Central Institute of Economic Management. Hanoi, Vietnam.

Colombo, M. G., \& Delmastro, M. (2002). The Determinants of Organizational Change and Structural Inertia: Technological and Organizational Factors. Journal of Economics \& Management Strategy, 11(4), 595-635. http://dx.doi.org/10.1162/105864002320757271

Gibbs, P. (1993). Determinants of Corporate Restructuring: The Relative Importance of Corporate Governance, Takeover Threat, and Free Cash Flow. Strategic Management Journal, 14(1), 51-68. http://dx.doi.org/10. 1002/smj.4250140906 
Harrison, J., Hitt, M. A., Hoskisson, R. E., \& Ireland, R. D. (1991). Synergies and post-acquisition performance: Differences versus similarities in resource allocation. Strategic Management Journal, 17(1), 173-190.

Hill, C. W. L., \& Scott, A. S. (1988). External Control, Corporate Strategy, and Firm Performance in Research Intensive Industries. Strategic Management Journal, 9(6), 577-590. http://dx.doi.org/10.1002/smj.425 0090605

Hoskisson, R. E., \& Turk, T. (1990). Corporate restructuring: Governance and control limits of the internal market. Academy of Management Review, 15, 459-477.

Jensen, M. (1986). Agency cost of free cash flow, corporate finance and takeovers. American Economic Review Papers and Proceedings, 76, 323-329.

King, D. R., Covin, J. G., \& Hegarty, W. H. (2003). Complementary resources and the exploitation of technological innovations. Journal of Management, 29(4), 589-606. http://dx.doi.org/10.1016/S0149-2063 (03)00026-6

Miller, D., \& Friesen, P. H. (1984). A Longitudinal Study of the Corporate Life Cycle. Management Science, 30(10), 1161-1183. http://dx.doi.org/10.1287/mnsc.30.10.1161

Moers, L. (2000). Determinants of Enterprise restructuring in Transition: Description of a Survey in Russian Industry. Tinbergen Institute Discussion Papers 00-026/2, Tinbergen Institute.

Soon, S. Y. (2004). The restructuring of the Korean economy following the financial crisis in 1997. International Journal of Management, 21(2), 232-239.

Tony, M. (1997). A strategic evaluation of re-engineering, restructuring, delayering and downsizing policies as flawed paradigm. Management Decision, 35(3), 240-249. http://dx.doi.org/10.1108/00251749710169459

\section{Appendix A}

\section{Questionnaire}

In order to implement the research "Problems and issues in corporate restructuring in State-Owned construction sector in Vietnam: the case of VINACONEX", we would like to ask you to fill in this questionnaire. Your opinions will substantially contribute to the outcome of this research topic. We look forward to receive your support as well as your thoughtful answers in this questionnaire. The information collected in this questionnaire is used for the purpose of the research only.

\section{A. Personal Information}

1. What is your gender: $\quad \square$ Male $\quad \square \quad$ Female

2. Which company are you working for, and what is your current position in your company?

Company:

Department: Position:

3. Education level

$\square$ College $\square$ University Graduation $\square$ Post Graduate and above

4. How long have you been working for VINACONEX?

$\square$ Under 5 years $\square$ 5-10 years $\square 10-15$ years $\square$ Above 15 years

\section{B. Problems and Issued Relating to Restructuring of State Owned Construction Enterprises}


Table A1. Pleased circle/tick your selected point which you consider the most appropriate level for respective questions. The points, which represent the increasing level of agreement, are ranging from 1 (strongly disagree) to 5 (strongly agreed)

\begin{tabular}{lll}
\hline No. Contents & $\begin{array}{l}\text { The level of } \\
\text { agreement } \\
\text { increasing }\end{array}$ & \begin{tabular}{c} 
is \\
\hline
\end{tabular} \\
\hline
\end{tabular}

1 The reasons for state-owned construction companies in Vietnam to implement the restructurings

1.1 Restructuring comes from the pressures and requirements of the Group/Parent Company/State Capital management Company/Industry/Government

1.2 Restructuring results from the urgent needs of the company to help it overcome recession, or avoid bankruptcy

$\begin{array}{lllll}1 & 2 & 3 & 4 & 5 \\ 1 & 2 & 3 & 4 & 5 \\ 1 & 2 & 3 & 4 & 5\end{array}$

Restructuring has arisen from the company itself with the objective of

1.3 self-renewal suitable with its strategy and the needs of the business development-identifying that restructuring is an indispensable phase in the development process of the company

2 Competition

2.1 Restructuring helps company compete more effectively

2.2 Restructuring helps companies focus their resources on their competitive products and the market

2.3 Restructuring helps companies focus on improving the quality of customer services, and enhancing the company' image and trademark

\section{Strategy}

3.1 In the context of Vietnam, construction companies should focus on their core business areas related to the construction industry

3.2 Having a clear strategy is a prerequisite to conduct restructuring. Otherwise, a hasty restructuring could result in decline, crisis, or even lead to bankruptcy.

3.3 Construction companies in Vietnam should expand their business in developing markets where infrastructure and construction is still underdeveloped

\section{Conflict}

4.1 Restructuring causes dissent amongst workers as well as trade unions In restructuring it is essential to dismantle and replace the old structure with a

4.2 new one, so that there is a sharp contrast between the old and the new in terms of conditions and benefits

4.3 Restructuring will require companies to put off staff which will mean they will also face fierce resistance from a number of their own managers and employees

\section{Ownerships}

The profound understanding and compatibility of the business operation fields of

5.1 the VINACONEX, who owned the main shares of the VINACONEX, will substantially affect the success or failure the VINACONEX

Enhancing the role of independent directors in the Board of Management shall

5.2 help keep the restructuring on the right track and improve the risk management of the VINACONEX

Contributions of state shareholders in companies are not realistic, and are poorly

5.3 effective for the business operations of the VINACONEX that have controlling shares owned by the State ( $>51$ percent)

\section{Leadership}

6.1 Restructuring must begin with the awareness of the leaders of the VINACONEX The Board of Management members, who directly manage the business

6.2 operations, will play the decisive role in the success or failure of the restructuring process in particular and the development of the VINACONEX in general

The qualification, knowledge and the profession of board members in the

6.3 operation fields of the VINACONEX will greatly impact on the success of the restructuring 


\begin{tabular}{|c|c|c|c|c|c|c|}
\hline No. & \multirow{2}{*}{$\begin{array}{l}\text { Contents } \\
\text { Employment }\end{array}$} & \multicolumn{4}{|c|}{$\begin{array}{l}\text { The level } \\
\text { agreement } \\
\text { increasing }\end{array}$} & \multirow[t]{2}{*}{$\begin{array}{l}\text { of } \\
\text { is }\end{array}$} \\
\hline & & & & & & \\
\hline 7.1 & Restructuring means the downsizing of staff of the VINACONEX & 1 & 2 & 3 & 4 & 5 \\
\hline 7.2 & $\begin{array}{l}\text { Restructuring is an opportunity to appropriately adjust key positions in the } \\
\text { VINACONEX and it is the right time to attract high quality human resources } \\
\text { from the outside of the VINACONEX }\end{array}$ & 1 & 2 & 3 & 4 & 5 \\
\hline 7.3 & $\begin{array}{l}\text { Restructuring help the VINACONEX to recognize the important role of human } \\
\text { resources strategy as well as its implementation }\end{array}$ & 1 & 2 & 3 & 4 & 5 \\
\hline 8 & Technological Innovation & & & & & \\
\hline 8.1 & One of the leading issues in the restructuring is technological innovation & 1 & 2 & 3 & 4 & 5 \\
\hline 8.2 & $\begin{array}{l}\text { Restructuring relating to technology should be defined as: "technological } \\
\text { innovation should be carried out before the current technology is outdated" }\end{array}$ & 1 & 2 & 3 & 4 & 5 \\
\hline 8.3 & $\begin{array}{l}\text { Technological innovation should be carried out continuously. Implementation of } \\
\text { technological innovation should not wait until restructuring. }\end{array}$ & 1 & 2 & 3 & 4 & 5 \\
\hline 9 & Corporate Governance & & & & & \\
\hline 9.1 & $\begin{array}{l}\text { Restructuring relating to corporate governance is to comprehensively reform the } \\
\text { management approach and methods in the VINACONEX }\end{array}$ & 1 & 2 & 3 & 4 & 5 \\
\hline 9.2 & $\begin{array}{l}\text { Establishing and building uniform regulations and procedures is necessary to } \\
\text { meet the strategy of the VINACONEX in accordance with the implementing of } \\
\text { the roadmap of the restructuring }\end{array}$ & 1 & 2 & 3 & 4 & 5 \\
\hline 9.3 & Mergers and acquisitions should occur more frequently & 1 & 2 & 3 & 4 & 5 \\
\hline 10 & Finance & & & & & \\
\hline 10.1 & $\begin{array}{l}\text { The merger, acquisition or sale of its affiliates/subsidiaries is actually to help } \\
\text { improve the financial condition of the companies }\end{array}$ & 1 & 2 & 3 & 4 & 5 \\
\hline 10.2 & $\begin{array}{l}\text { There should be a specific policy regarding "capital preservation requirements" } \\
\text { for selling projects/shares of state owned enterprises/companies with controlling } \\
\text { shares owned by the State }\end{array}$ & 1 & 2 & 3 & 4 & 5 \\
\hline 10.3 & $\begin{array}{l}\text { Inconsistent policies of the state on capital preservation requirements for selling } \\
\text { shares or conducting merger are creating obstacles for the restructuring process }\end{array}$ & 1 & 2 & 3 & 4 & 5 \\
\hline
\end{tabular}

Thank you very much for your time to complete this Questionnaire!

\section{Copyrights}

Copyright for this article is retained by the author(s), with first publication rights granted to the journal.

This is an open-access article distributed under the terms and conditions of the Creative Commons Attribution license (http://creativecommons.org/licenses/by/3.0/). 